\title{
Spices for taming the COVID-19 pandemic: Prospects and perspectives
}

\author{
S J Eapen \\ ICAR-Indian Institute of Spices Research, Kozhikode, Kerala - 673 012, India \\ E-mail: santhosh.eapen@icar.org.in
}

Received 07 June 2021; Revised 19 June 2021; Accepted 19 June 2021

\begin{abstract}
Coronavirus Disease 2019 (COVID-19), first reported in December 2019 from Wuhan in China, had reached the stage of a pandemic. To date (28.06.2021), there are more than 181.9 million confirmed cases of the disease in the world. Even though vaccines have been developed, antiviral drugs are yet to be developed for management and treatment of SARS-CoV-2. Since several medicinal plants are used in traditional medicines, though with controversial efficacy claims, they can be considered as sources of new antiviral drug compounds against emerging viruses. In this context, spices are noteworthy as their anti-oxidant, anti-viral, anti-inflammatory and immunostimulatory properties are well studied and documented. The emerging scientific literature includes a number of papers on the anti-SARS-CoV-2 activity of spice extracts and specific compounds proven through different types of laboratory experiments. Here, the information pertaining to anti-viral properties of spice-based phytochemicals or natural compounds (not crude extracts) is summarized in this review. Spice-based compounds discussed here are an option for testing in COVID-19 patients though we don't have strong data to support their active recommendation. Because of their natural origin, safety, and low cost, they can be a viable option in our fight against viruses and this compilation may be useful for planning and designing more robust experiments in future.
\end{abstract}

Keywords : anti-oxidant properties, anti-inflammatory properties, anti-viral properties, COVID-19, immunostimulatory properties, SARS-CoV-2, spices

\section{Introduction}

Coronavirus Disease 2019 (COVID-19) is a public health emergency affecting all populations cutting across different countries. The first report of this ongoing pandemic was from Wuhan in China in December 2019. Since then $181,865,998$ cases have been reported across the world till 28 June 2021 (https://www. worldometers.info/coronavirus/). On 11 March 2020, the World Health Organization (WHO) declared it a global pandemic, because of its rapid spread across the globe within a shortspan of time (Cucinotta \& Vanelli 2020). Today no countries are left untouched by the COVID-19 pandemic. A novel human coronavirus $(\mathrm{HCoV})$, severe acute respiratory syndrome coronavirus 2 (SARS-CoV-2), is identified as the causative pathogen of COVID-19 (Rabi et al. $2020)$. Belonging to the genera, $\beta$-coronavirus of the Coronaviridae family (Naqvi et al. 2020), it is the third zoonotic coronavirus disease after 
Severe Acute Respiratory Syndrome (SARS) and the Middle East Respiratory Syndrome (MERS) (Sun et al. 2020).

\section{Novel Coronavirus}

\section{Structure}

The genome of this virus is composed of $\sim 30,000$ nucleotides with 14 ORFs encoding 27 proteins. It comprises four important structural proteins viz. the envelope (E), spike (S), membrane (M), and nucleocapsid (N) proteins (Lu et al. 2020). The $\mathrm{M}$ protein of $25-30 \mathrm{kDa}$ size gives shape to the virus while another protein of 8-12 kDa, $\mathrm{E}$ protein, promotes viral release. Together, they are responsible for the viral assembly and maturation of viral envelopes (Schoeman \& Fielding 2019). On the other hand, the $N$ protein, located in the core of the viral particle, plays an essential role in viral packaging and helps in the formation of the nucleocapsid (Ashour et al. 2020). The S protein (150 kDa) consisting of S1 and S2 subunits is responsible for the characteristic spike-like protrusions on the virus. The virus entry into the host cells is facilitated by a receptor-binding domain (RBD) in the S1 subunit that binds to the host receptor angiotensin-converting enzyme 2 (ACE2) and the S2 subunit that fuses with the cell membrane of the host (Masters 2006; Fehr \& Perlman 2015; Astuti \& Ysrafil 2020).

\section{Pathogenesis}

As mentioned earlier, the attachment and fusion of the virus with the host cell is facilitated substantially by the $S$ protein. The SARS-CoV-2 severely affects oral, nasal and respiratory regions, cornea, heart, kidneys, etc. as the virus has greater affinity to human ACE2 (hACE2) receptors prevalent there (Sungnak et al. 2020; Xu et al. 2020; Zhou et al. 2020). The enzyme furin mediates the cleavage of the SARS-CoV-2 S protein at the S1/S2 site and pre-activates the $S$ protein to promote the subsequent type II transmembrane serine protease (TMPRSS2)-dependent viral entry into the host cells (Astuti \& Ysrafil 2020; Shang et al. 2020). TMPRSS2 primes the ACE2 receptor- bound viral S protein and its higher expression is observed in the tissues mentioned above. SARS-CoV-2 is dependent on both Cathepsin $\mathrm{B} / \mathrm{L}(\mathrm{CatB} / \mathrm{L})$ and TMPRSS2 or in the absence of any one of them, the other enzyme for its entry to host cells (Hoffmann et al. 2020). On gaining entry, its genomic material (mRNA) is liberated in the cytoplasm which takes control of the protein synthesis machinery in the host leading to seamless viral replication (Astuti \& Ysrafil 2020).

The mode of action of SARS-CoV-2 and the pathophysiological mechanism of COVID-19 are being studied across the globe. The evidence gathered so far indicates a steep rise in the cytokine levels in COVID-19 patients leading to severe deterioration of health conditions, multi-organ failure and death (Yi et al. 2020). The medical condition is termed as "cytokine storm" or "cytokine release syndrome". Various chemokines, colonystimulating factors, interferons, interleukins and tumor necrosis factor- $\alpha$ (TNF- $\alpha$ ) are involved in this hyperactive immune response. In severely affected patients, interleukins like IL-2R, IL-6 and IL-10 are elevated while the absolute count of CD4+ T, CD8+ T, and B cells are gradually reduced (Wang et al. 2020). Inflammatory enzymes like cyclooxygenase (cox)-1 and -2, matrix metalloproteinase (MMP)-9, 5-lipoxygenase (5-LOX) and an array of transcription factors - signal transducer and activator of transcription 3 (STAT3), nuclear factor kappa-B (NF- $\kappa \mathrm{B})$, nuclear factor erythroid 2-related factor 2 (Nrf2), activator protein-1 (AP-1), nuclear factor of activated $\mathrm{T}$ cells (NFAT), and hypoxia-inducible factor- $1 \alpha$ $(\mathrm{HIF}-1 \alpha)$ are the other key molecular mediators of inflammation (Kunnumakkara et al. 2021). Mortality in COVID-19 is primarily due to respiratory failure and comorbidities like hypertension and cardiac anomalies aggravate the condition. TNF- $\alpha$, an inflammatory cytokine produced by macrophages/monocytes, has a key role to play in pulmonary edema caused during COVID-19-associated lung diseases (Ye et al. 2020). Nrf2, the most potent and ubiquitous master transcription factor in humans, can downregulate the oxidative stress 
from the $\mathrm{AT}_{1} \mathrm{R}$ axis as well as in the endoplasmic reticulum (Vomund et al. 2017).

Several COVID-19 symptoms like cough, taste and smell disorders, loss of appetite, nasal obstruction, nausea, diarrhea etc. are associated with the transient receptor potential (TRP) vanilloid 1 (TRPV1) and ankyrin 1 (TRPA1) cation channels belonging to TRP superfamily (Fernandes et al. 2012). TRPA1 and/or TRPV1 are co-localized in sensory neurons and many non-neuronal cells viz. vascular smooth muscle, monocytes, lymphocytes, keratinocytes, epithelial cells, and endothelium. TRPA1, playing a key role in the physiology of almost all organs, induces inflammation, while TRPV1 detects and regulates body temperature (Fernandes et al. 2012). Both the TRP ion channels are associated with control of weight, pancreatic function, hormone secretion, thermogenesis, and neuronal function and are sensory receptors for multiple products of oxidative stress (Bousquet et al. 2021). They, especially TRPV1-expressing neuronal systems (afferent/efferent neurons) in the lungs, are closely linked with many physiological events that lead to mortality.

\section{Potential therapeutic agents}

The alarming pace of the COVID-19 pandemic spread has prompted scientists and researchers around the globe to explore various therapeutics to fight against it. Initially, several repurposed drugs showed promising efficacy and further investigations are on to accurately evaluate them (Fisher \& Heymann 2020; Kunnumakkara et al. 2021). Promising ones among them are Chloroquine, Hydroxychloroquine, Ivermectin, Niclosamide, Azithromycin, Remdesvir, Lopinavir, etc. Since COVID-19 targets the immune system of the host, there are several reports on many herbal agents being recommended as an adjunct therapy or as prophylactic agents (Boukhatem \& Setzer 2020; Khanna et al. 2021; Patel et al. 2021). NF$\kappa \mathrm{B}$ can be a potential target for inflammationbased viral therapy, as it regulates several vital physiological processes and is actively involved in the development of adaptive and innate immunity (Hayden et al. 2006). Plant compounds are able to target the multiple steps in the NF- $\kappa \mathrm{B}$ pathway like hindering the phosphorylation or the ubiquitination of signalling molecules or blocking the interaction between the NF- $\kappa \mathrm{B}$ and the target DNA by binding to the target DNA and shutting off its transcriptional activity (Gupta et al. 2010; Seo et al. 2018). Recently there are many reviews and commentaries on promising dietary and herbal remedies against COVID-19 (Ang et al. 2020; Damaris et al. 2020; Fan et al. 2020; Panyod et al. 2020). A rapid- response preliminary survey carried out in five metropolises and 12 rural areas or countries during the first phase of the pandemic has clearly indicated that several homemade plant-based remedies have been repurposed and the consumption of ginger and garlic, onion, turmeric, and lemon has increased tremendously (Pieroni et al. 2020).

\section{Spices and COVID-19}

For centuries, spices were sought after not just because of their aroma, pungency or taste but as food flavorings and folk medicines. Due to their medicinal properties, traditionally they have been used in Ayurveda and Chinese traditional medicine to cure several chronic ailments. Their antioxidant, anti-inflammatory and immunomodulatory properties are well documented (Gupta 2010; Yashin et al. 2017; Jiang 2019). The health impacts of culinary spices and herbs have been compiled as a structured database - SpiceRx (https://cosylab.iiitd.edu.in/ spicerx/), and is available in the public domain (Rakhi et al. 2018). Their vital role in enriching flavor, improving digestion, and supporting human health by way of their antioxidant and immune boosting properties is much discussed during this pandemic. The characteristic aroma and flavor of spices is primarily due to the rich essential oils present in them. A number of phenolics like flavonoids, phenolic acids, tannins, and quinones are present in spices. These secondary metabolites are considered to have anti-inflammatory, antioxidant and immunomodulatory properties and have the potential to boost immunity with apparently no side-effects. Exhaustive compilations on the role of spices in regulating the 'cytokine storm' 
have been made by Kunnumakkara and others (2018, 2021).

But in a recent paper published by American Chemical Society Neurosciences, Elsayed \& Khan (2020) have analyzed the number of total COVID-19 cases, total deaths, and total recovered from 163 countries. The study indicated that there is a clear interrelation between the total number of COVID-19 cases per million population tested and the gram of spice supply per capita per day. Subsequently, many others have pointed out the large geographical variations in the disease prevalence, severity, and mortality (Bousquet et al. 2020a; Rocha \& de Assis 2020).

\section{Antioxidant properties}

COVID-19 leads to accumulation of reactive oxygen species (ROS) as conversion of $\mathrm{O}_{2}$ to $\mathrm{H}_{2} \mathrm{O}_{2}$ and then reduction to $\mathrm{H}_{2} \mathrm{O}$ by glutathione $(\mathrm{GSH})$ redox system is impaired. Several studies have reported that many spices contain a number of phenolics which act as strong antioxidants (Shahidi \& Ambigaipalan 2015; Yashin et al. 2017). They help to control the cellular oxidative stress by controlling the production of ROS. Their functional bioactive ingredients in spices arrest the activity of cytochrome P450 and isozymes CYP 1A1, cyclooxygenase-2, reducing signal transducer and activator of transcription-3 (STAT-3). They trigger the free radicals scavenging ability at cellular level and thereby alleviate various metabolic syndromes. Different mechanisms are operating for the antioxidant activity properties of these compounds which include direct or indirect activation of the nuclear factor, Nrf2, that plays a major role in the modulation of TRP (transient receptor potential) A1 by ROS (Bousquet et al. 2020b). Many Nrf2-interacting pungent compounds from spices like allicin from garlic, capsaicin from chilli, cinnamaldehyde from cinnamon, curcumin from turmeric, eugenol from clove gingerols from ginger and piperine from black pepper are TRPA1 and TRPV1 agonists (Bousquet et al. 2020a). For example, curcumin scavenges ROS as a polyphenolic antioxidant by upregulating SOD2, a key enzyme in redox homeostasis (Hemeida \& Mohafez 2008; Wang et al. 2008; Forrester et al. 2018).

\section{Immunomodulatory properties}

The human immune system, the first barrier to infection and disease, activates inflammation and plays a key role in the defense against several infectious diseases including COVID-19. The invasion and pathogenesis of SARS-CoV-2 are associated with the host antiviral immune response which is crucial to eliminate the invading virus. A weak immune mechanism coupled with cytokine surge leads to decreased cellular oxygenation which is reported to be the main cause of COVD19 mortality (Kunnumakkara et al. 2018). Functional ingredients from a variety of plants including spices act as immune boosters and diminish inflammatory disorders. Essential oils have several immune supporting properties and are used in aromatherapy. Recently Peterfalvi et al. (2019) have reviewed the immune function enhancing role of essential oils. Products and treatment involving these essential oils help our body to develop natural resistance against many diseases. The major spice oils that are known for their immune boosting properties include cardamom, ginger, clove, and cinnamon. Prominent spice compounds with proven immune boosting properties include curcumin, piperine, gingerols, cinnamaldehyde, caryophyllene, eugenol, curcumin and its derivatives.

Curcumin: Curcumin, the principal curcuminoid from turmeric (Curcuma longa L.), is commonly used as a spice, food additive and dietary pigment. The immunomodulatory effects of curcumin on various aspects of the immune response are being studied intensively after the Covid pandemic. A summary of the bioactivity and health benefits of curcumin was published recently ( $\mathrm{Xu}$ et al. 2018). The potent biological activities of curcumin is dependent on its metabolism as it is present in the mammalian body in three major forms, which are free, conjugated, and reduced states. Curcumin is metabolized into conjugated 
curcumin on oral administration, while intravenous or intraperitoneal administration mainly leads to reduced curcumin. Multiple signaling pathways, including $N F-\kappa B$ and STAT3 signaling, are involved as the molecular mechanisms underlying the targets of curcumin. Treatment with curcumin reduces inflammation by influencing several signaling pathways viz. S-nitrosylation on IKK $\beta$, phosphorylation-I $\kappa \mathrm{B}$, and binding with MD2 and by suppressing NF- $\kappa \mathrm{B}$ activation and thereby increasing HO-1 activity. However, curcumin's poor bioavailability is a major barrier to its clinical efficacy.

Piperine: Piperine, the most active compound present in black pepper (Piper nigrum L.) fruits, possesses several properties. It acts as a bioavailability enhancer, especially in combination with other drugs or nutraceuticals, like curcumin. Piperine modifies curcumin's extensive immunomodulating, antioxidant, chemopreventive and anticancer activities which are dose-dependent and tissue-specific. However, again the main disadvantage associated with piperine is its low bioavailability, which is being overcome with innovative formulations.

Gingerols: Ginger (Zingiber officinale Rosc.) has been used as a food, spice, supplements, flavoring agent and in traditional medicines. 6-Gingerol is the most important bio-active ingredient in ginger well-known for its pharmacological and physiological actions.

Cardamonin: Cardamonin is a cardamomderived chalcone, having significant roles in cancer treatment, immune system modulation, inflammation and killing of pathogens. It is emerging as a promising novel experimental anticancer agent because of its relatively selective cytotoxic potential against host malignant cells.

Cinnamomum (Family Lauraceae) is a traditional spice used for flavouring and pharmaceutical purposes. A wide range of phytochemical compounds are found in various parts of these plants. Cinnamon is proven to harbour an array of properties such as anti- inflammatory, antimicrobial, antioxidant, antitumor, cardiovascular, cholesterollowering, and immunomodulatory effects, the most promising being its use in treating type 2 diabetes mellitus.

\section{Antiviral properties}

Plants from tropical or temperate regions are a potential source of untapped antiviral activity. Tapping this major source of herbal remedies is an ideal strategy for discovering new antiviral pharmaceutical molecules (Astani et al. 2011). Many of them interact with various molecular targets to trigger cellular signaling pathways like apoptosis and inflammation. Some lead compounds from spices, reported to possess anti-viral properties, are listed in Table 1. Curcumin is the most potential one among them as it interacts directly with multitude of proteins modulating intercellular signaling cascades essential for virus replication and affecting different cellular post-transcriptional and post-translational modifications that limit viral multiplication (Mathew \& Hsu 2018; Praditya et al. 2019).

\section{Anti-inflammatory properties}

Innumerable studies are there confirming the anti-inflammatory properties of spices, mostly using their crude extracts, which have been reviewed earlier (Kunnumakkara et al. 2018). However recent studies using modern scientific tools have deciphered the potential mode of action of several phytochemicals present in spices (Table 2). Prominent among these are piperine, piperlongumine, curcumin, diallyl sulfide, gingerols, garcinol etc. Most of them downregulate the elevated LPSinduced mRNA expression of key interleukins, cytokines and inducible nitric oxide synthase (iNOS) and also inhibit the activation of two key signaling pathways, NF- $\kappa \mathrm{B}$ and STAT. Trigonelline from fenugreek gives neuroprotection by decreasing hippocampal glial fibrillary acidic protein (GFAP) and proinflammatory cytokines (Fahanik-Babaei et al. 2019). Garcinol, a major component of Garcinia, significantly reduces inflammation by regulating mediators like iNOS and cox-2, 


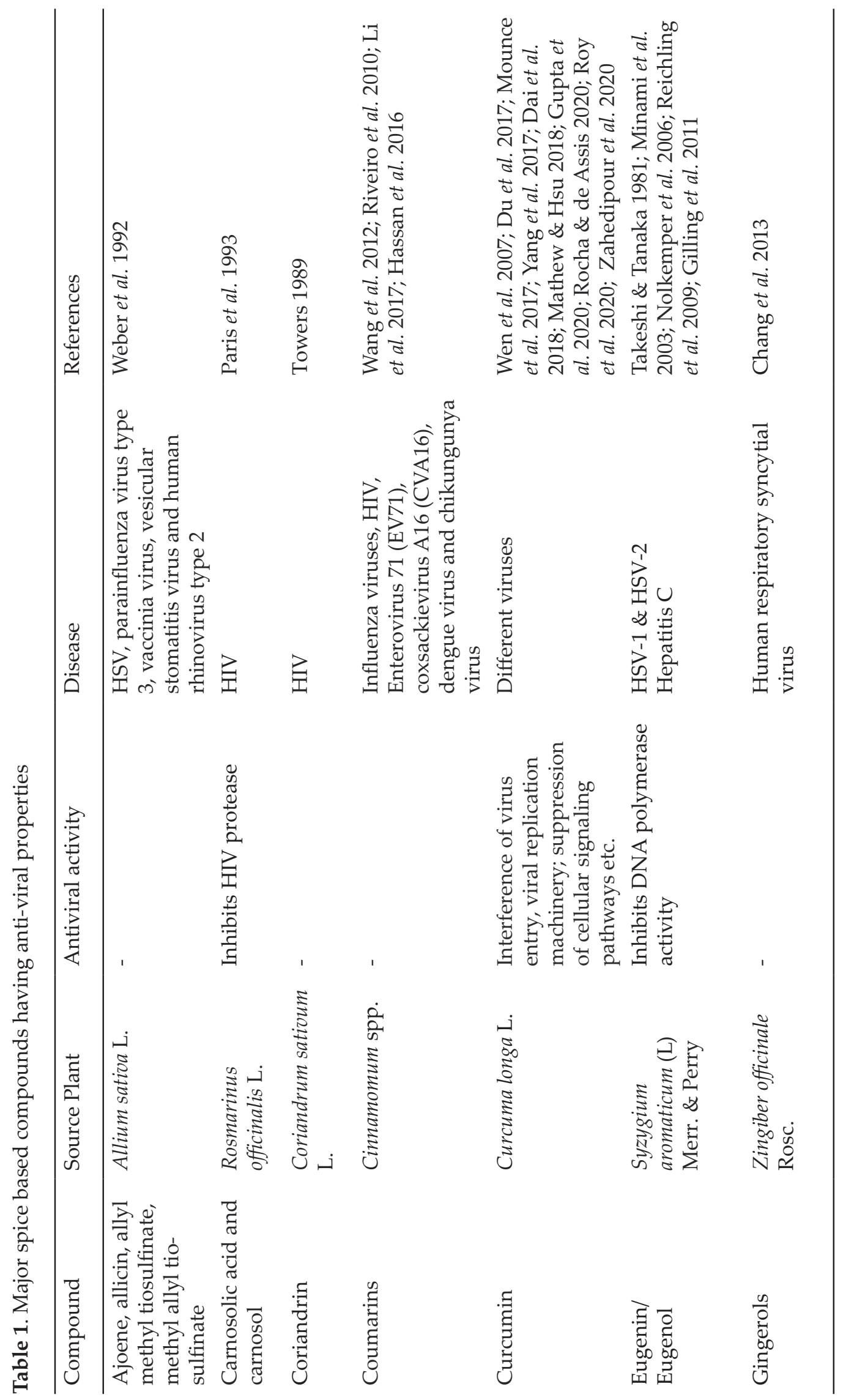




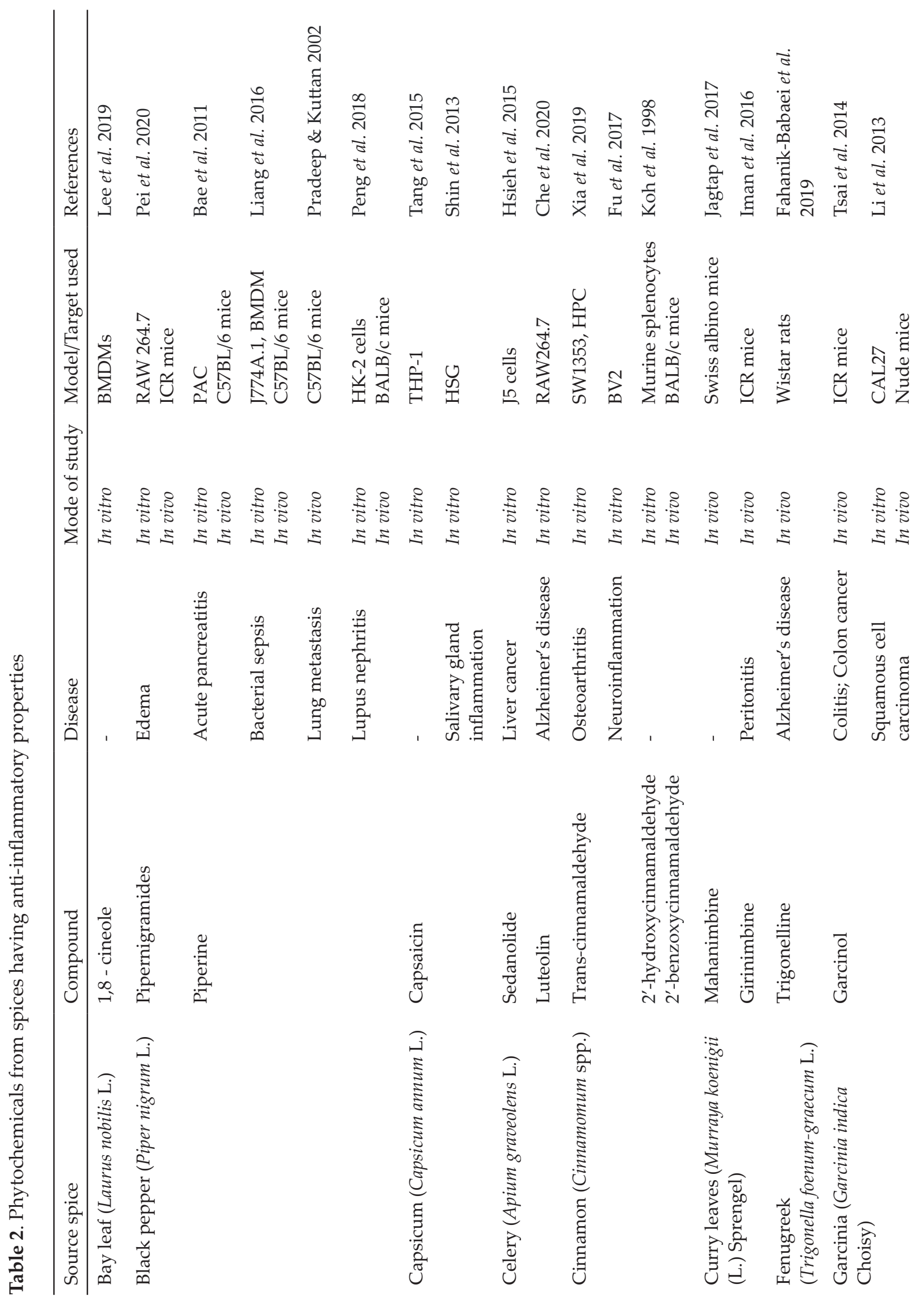




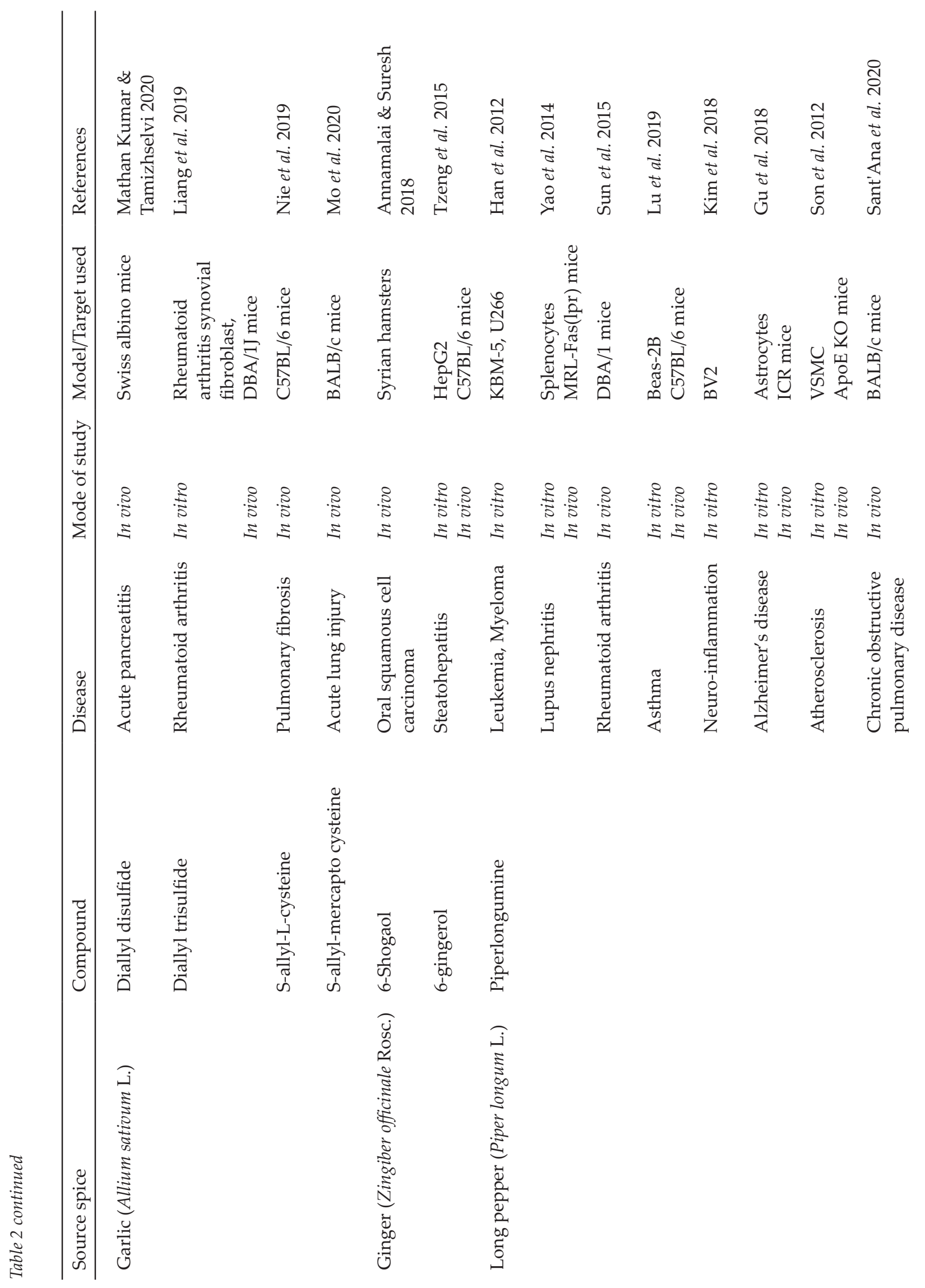




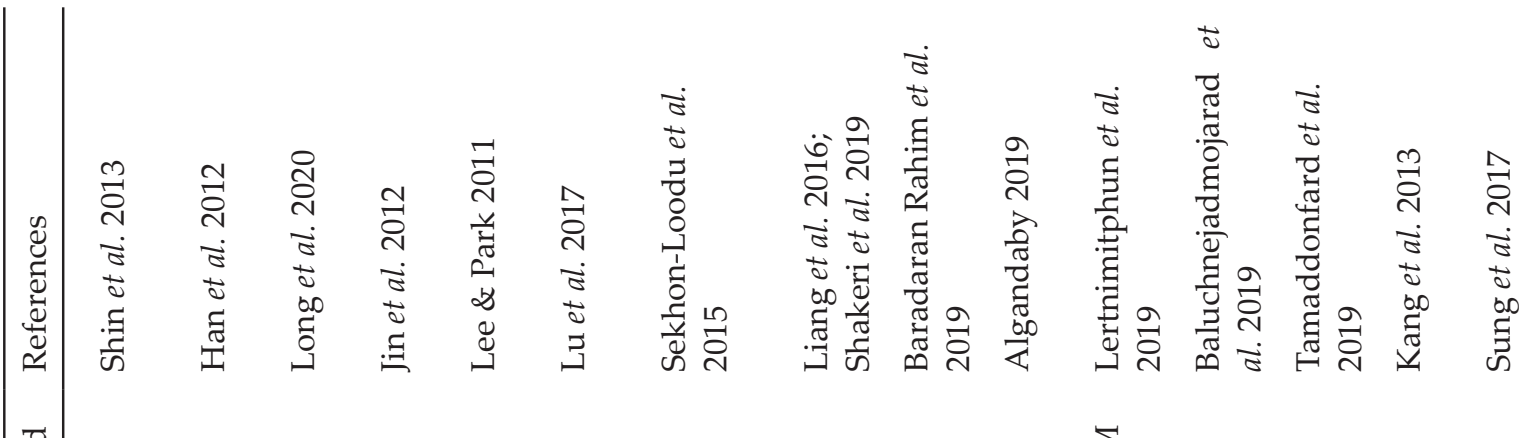

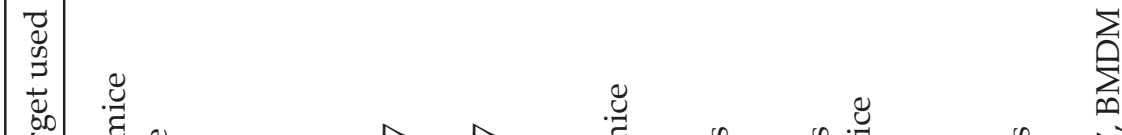

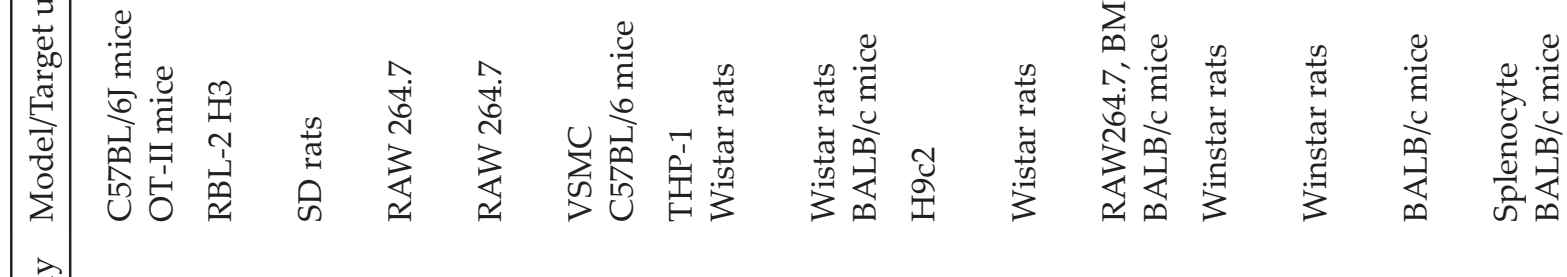

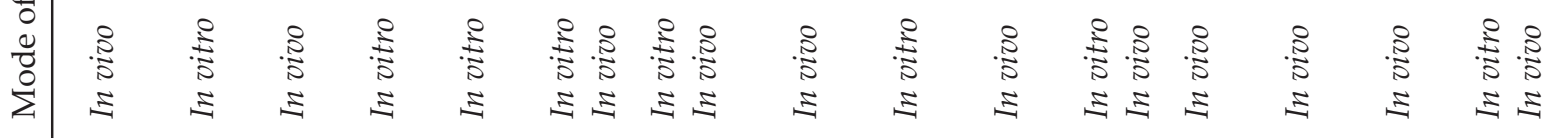

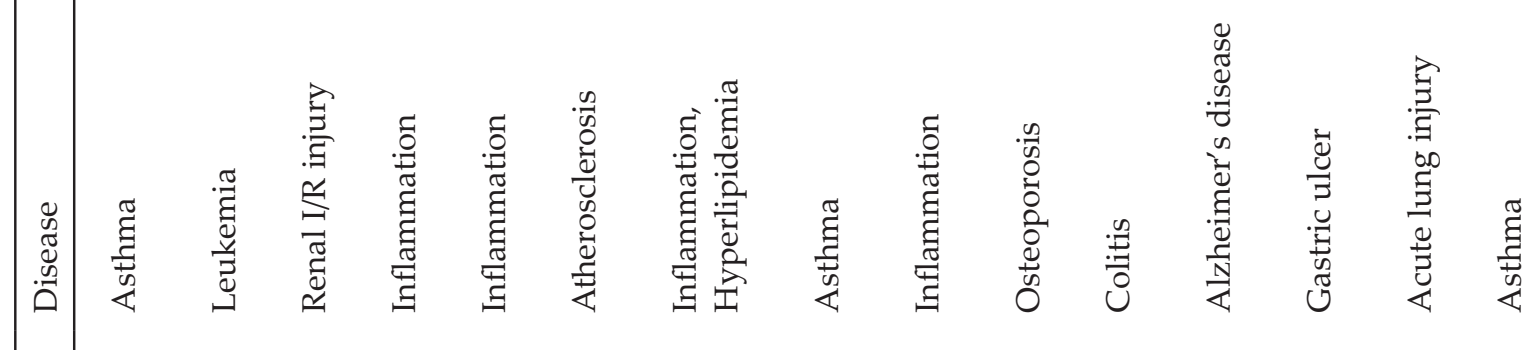
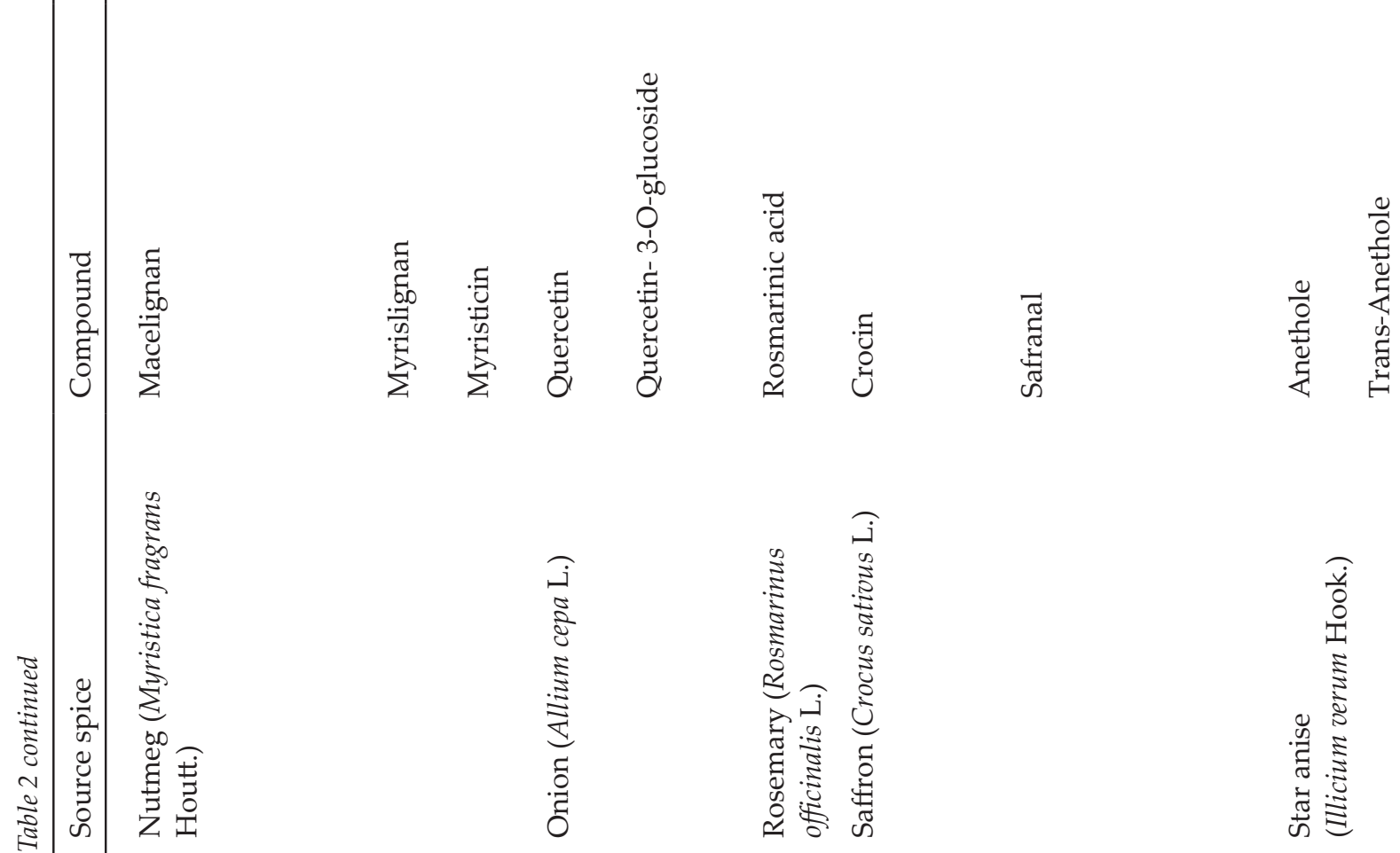
prevents colon tumorigenesis, and exerts antitumor effects (Li et al. 2013; Tsai et al. 2014). Similarly myristicin from nutmeg also inhibits production of cytokines and chemokines (Lee \& Park 2011). Anti-inflammatory activity of curcumin (Funamoto et al. 2016; Amalraj et al. 2017; Panahi et al. 2017; Samadian et al. 2017; Adibian et al. 2019), curcuminoids (Panahi et al. 2015a,b; Uchio et al. 2019) and nanocurcumins (Abdolahi et al. 2019) have been unambiguously proved in several clinical trials.

\section{Spices against SARS-CoV-2}

Across the globe there are innumerable studies on the therapeutic properties of spices which are summarised in this review. After the outbreak of SARS-CoV-2, researchers from various laboratories have intensively explored the potential of several natural compounds and phytochemical extracts against this new virus. Table 3 summarises such exploratory studies on different strains of novel coronavirus. Many of these are computational studies predicting the potential of spice molecules against the SARS-CoV-2 targets. Molecular modeling analysis is extensively used in such studies to screen the potential therapeutic ability of these compounds to bind with key targets like main protease - Mpro, fusion spike protein, human ACE2 receptor, RNA-dependent RNA polymerase, N-protein, E protein, RNAbinding $\mathrm{N}$ terminal domain (NTD) of the $\mathrm{N}$ protein and 3CL hydrolase (Wu et al. 2020; Joshi et al. 2021). The leads obtained need to be validated experimentally for developing rigid and highly specific treatment options against COVID-19. The array of positive leads obtained from in silico studies necessitates the need for robust pre-clinical and clinical research of the predicted compounds to develop effective future therapeutics against COVID-19. Two compounds that stand out are curcumin and piperine showing promising results in the initial clinical trials. The clinical studies, though few in number, have contributed to develop a proof-of-concept underlining an interplay between TRPA1 and TRPV1 in desensitization and the synergistic role of Nrf2 (Bousquet et al. 2020a). 


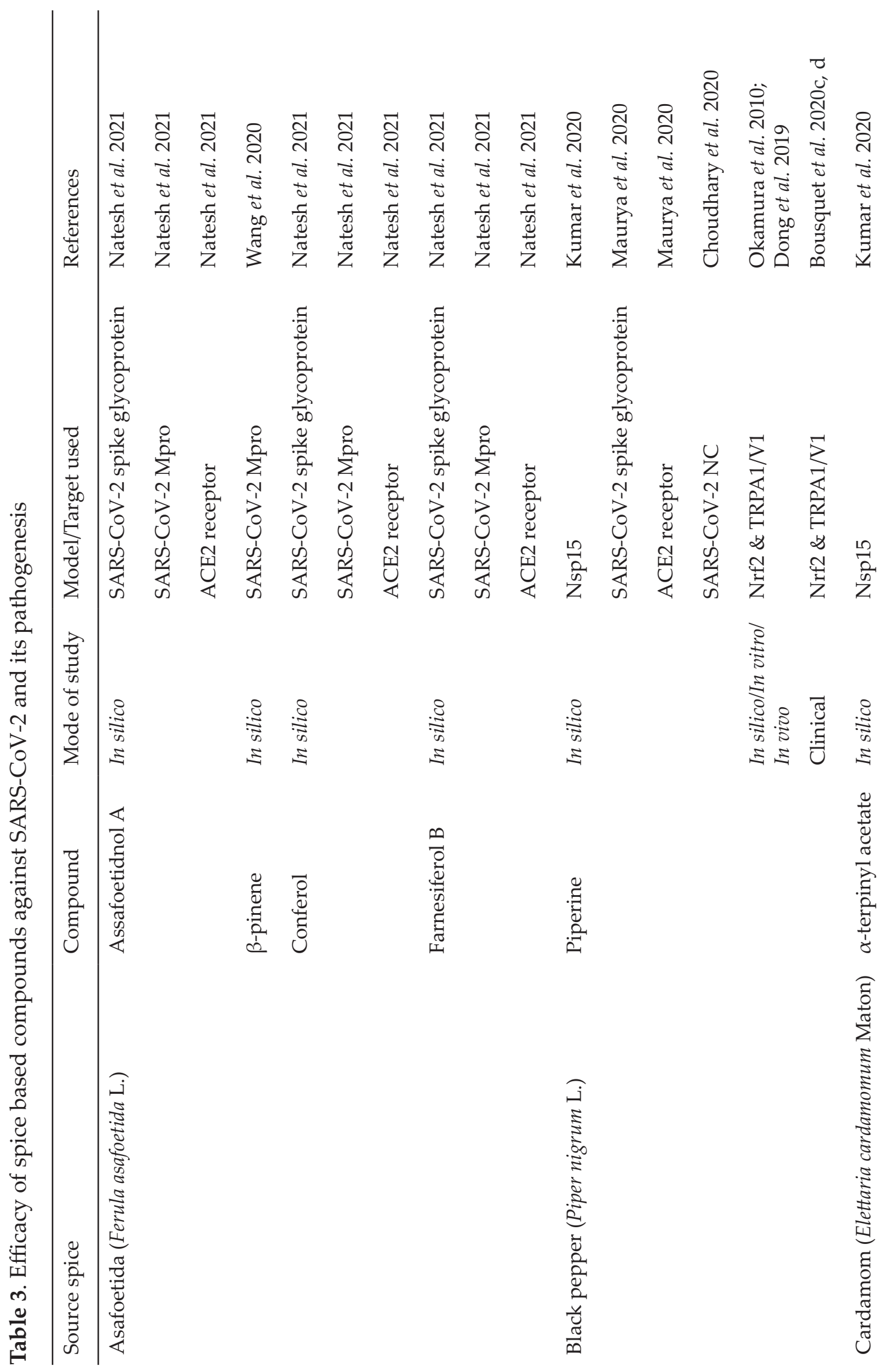




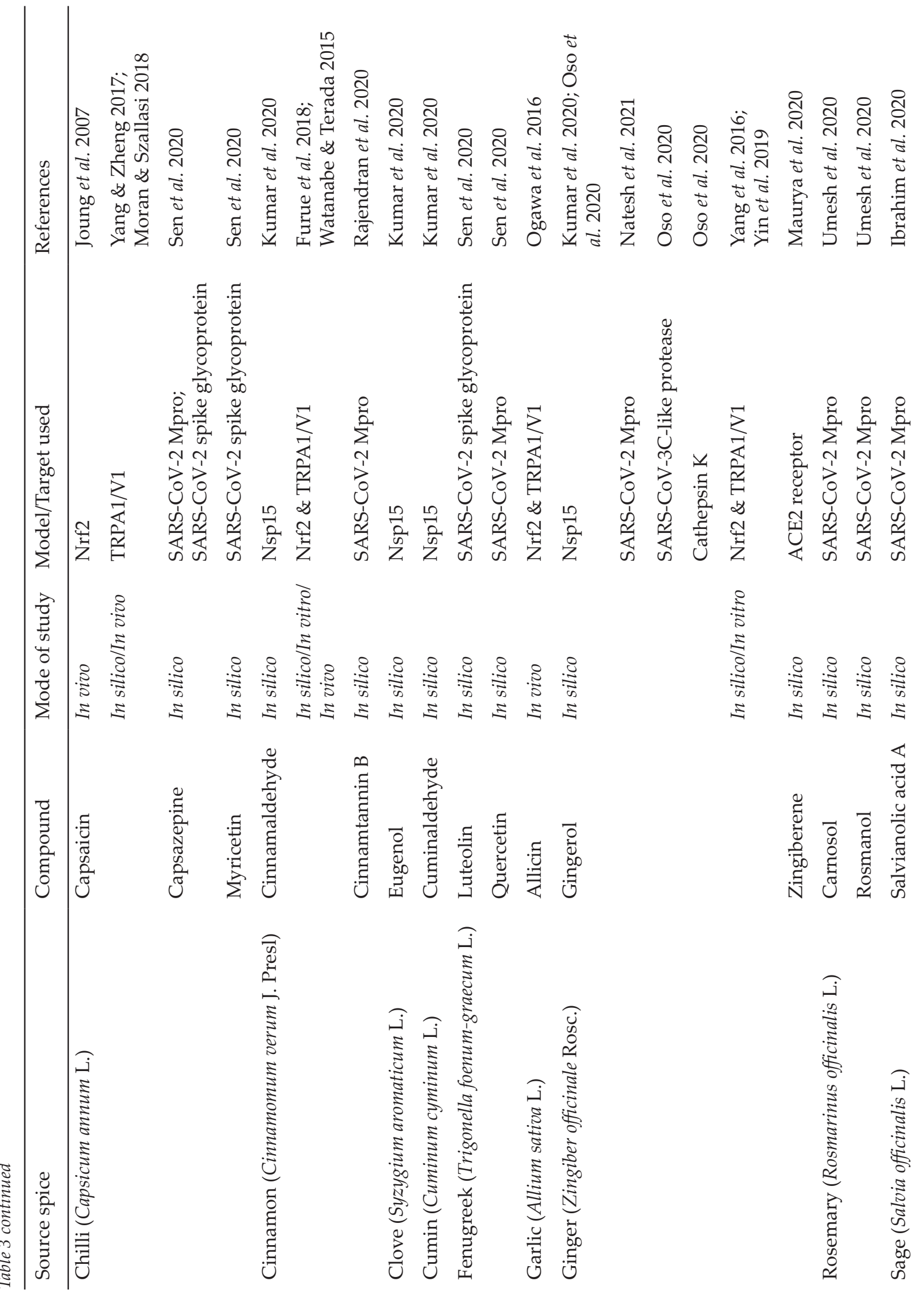




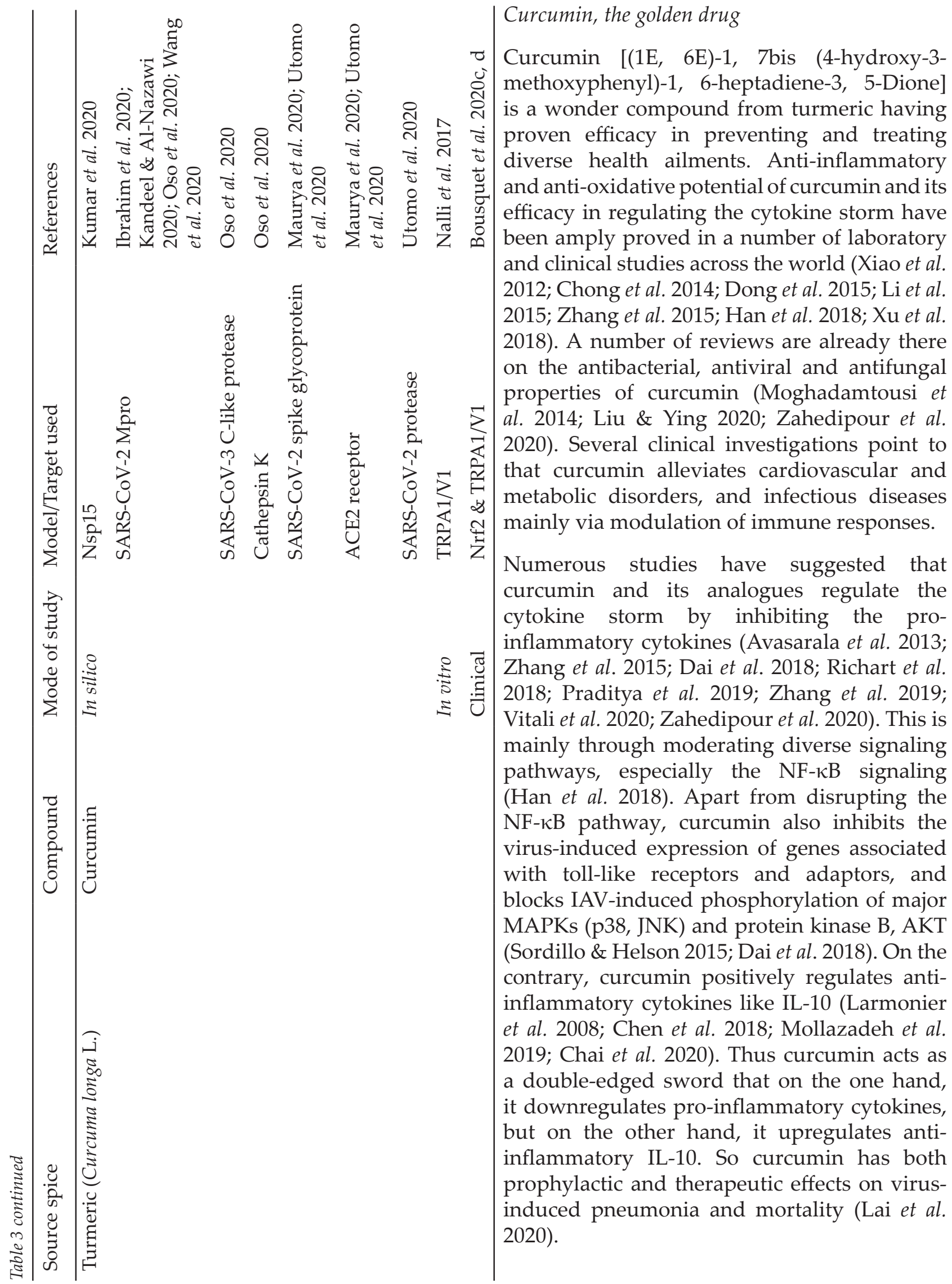


Curcumin reduces collagen deposition, expression of myofibroblasts and slows down the development of pulmonary fibrosis (Amini et al. 2018; Li et al. 2020). Combined application of vitamin C, curcumin and glycyrrhizic acid was found effective against this virus by regulation of crucial pathways (Kandeel \& Al-Nazawi 2020). Clinical studies using nanoencapsulated curcumin significantly reduced symptoms of COVID-19 (fever, cough, and dyspnea) (Tahmasebi et al. 2020; Valizadeh et al. 2020).

\section{Future prospects}

Antiviral and anti-inflammatory activities of several natural substances have been amply demonstrated in the past and preclinical studies carried out across the world offer mounting evidence. Their potential to inhibit or alter the configuration of structural, non-structural and accessory proteins coded by SARS-CoV-2 genome has been thoroughly explored in these studies. Thus, such natural substances from spices can reduce the severity of COVID-19 symptoms and may seem promising as effective treatments against COVID-19. Among them, curcumin and piperine could be considered as attractive alternatives for managing coronavirus infections, in view of their preventative and therapeutic role proved through recent clinical trials. Even at high concentrations, curcumin is a well-tolerated natural compound in humans. Therefore, it appears logical to combine it with drugs that are already approved for use. However, we need further detailed experimental evaluation and clinical validation to implement them as potent therapeutic agents against SARS-CoV-2.

As of now, SARS-CoV-2 infection is not amenable to any specific treatment. With the onset of the pandemic, especially its second wave, public health services have dramatically failed in multiple countries. In such challenging times, food medicines have a major role to play in maintaining holistic well-being of communities. So apart from understanding the alleged biological activities of spices, it is high time that we pay more attention to study the trustworthiness and scientific accuracy of spice based food medicines in community health systems. Such an approach will help in designing a global health strategy that is more robust, institutionalized, affordable and sustainable.

\section{References}

Abdolahi M, Jafarieh A, Sarraf P, Sedighiyan M, Yousefi A, Tafakhori A, Abdollahi H, Salehinia F \& Djalali M 2019 The neuromodulatory effects of $\omega$-3 fatty acids and nano-curcumin on the COX-2/ iNOS network in migraines: A clinical trial study from gene expression to clinical symptoms. Endocr. Metab. Immune Disord. Drug Targets 19: 874-884.

Abulfadl Y S, El-Maraghy N N, Ahmed A E, Nofal S, Abdel-Mottaleb Y \& Badary O A 2018 Thymoquinone alleviates the experimentally induced Alzheimer's disease inflammation by modulation of TLRs signaling. Hum. Exp. Toxicol. 37: 1092-1104.

Adibian M, Hodaei H, Nikpayam O, Sohrab G, Hekmatdoost A \& Hedayati M 2019 The effects of curcumin supplementation on high-sensitivity C-reactive protein, serum adiponectin, and lipid profile in patients with type 2 diabetes: A randomized, double-blind, placebo-controlled trial. Phytother. Res. 33: 1374-1383.

Algandaby M M 2019 Crocin attenuates metabolic syndrome-induced osteoporosis in rats. J. Food Biochem. 43: e12895.

AmalrajA, Varma K,JacobJ, Divya C, Kunnumakkara A B, Stohs S J \& Gopi S 2017 A novel highly bioavailable curcumin formulation improves symptoms and diagnostic indicators in rheumatoid arthritis patients: A randomized, double-blind, placebo-controlled, two-dose, three-arm, and parallel-group study. J. Med. Food 20: 1022-1030.

Amini P, Saffar H, Nourani M R, Motevaseli E, Najafi M, Ali Taheri R \& Qazvini A 2018 Curcumin mitigates radiation-induced lung pneumonitis and fibrosis in rats. Int. J. Mol. Cell Med. 7(4): 212-219.

Ang L, Song E, Lee H W \& Lee M S 2020 Herbal medicine for the treatment of coronavirus disease 2019 (COVID-19): A systematic review and meta-analysis of randomized 
controlled trials. J. Clin. Med. 9: 1583 https:// doi.org/10. 3390/jcm9051583.

Annamalai G \& Suresh K 2018 [6]-Shogaol attenuates inflammation, cell proliferation via modulate NF- $\kappa B$ and AP-1 oncogenic signaling in 7,12-dimethylbenz[a]anthracene induced oral carcinogenesis. Biomed. Pharmacother. 98: 484- 490 .

Ashour H M, Elkhatib W F, Rahman M M \& Elshabrawy H A 2020 Insights into the recent 2019 novel coronavirus (SARS-CoV-2) in light of past human coronavirus outbreaks. Pathogens 9: 186.

Astani A, Reichling J \& Schnitzler P 2011 Screening for antiviral activities of isolated compounds from essential oils. Evid. Based Complement. Alternat. Med. 2011: 8.

Astuti I \& Ysrafil 2020 Severe acute respiratory syndrome coronavirus 2 (SARS-CoV-2): An overview of viral structure and host response. Diabetes Metab. Syndr. 14: 407-412.

Avasarala S, Zhang F, Liu G, Wang R, London S D \& London L 2013 Curcumin modulates the inflammatory response and inhibits subsequent fibrosis in a mouse model of viralinduced acute respiratory distress syndrome. PLoS One 8(2): e57285.

Bae G S, Kim M S, Jeong J, Lee H Y, Park K C, Koo B S, Kim B J, Kim T H, Lee S H, Hwang S Y, Shin Y K, Song H J \& Park S J 2011 Piperine ameliorates the severity of cerulein- induced acute pancreatitis by inhibiting the activation of mitogen activated protein kinases. Biochem. Biophys. Res. Commun. 410: 382-388.

Baluchnejadmojarad T, Mohamadi-Zarch S M \& Roghani M 2019 Safranal, an active ingredient of saffron, attenuates cognitive deficits in amyloid $\beta$-induced rat model of Alzheimer's disease: Underlying mechanisms. Metab. Brain Dis. 34: 1747-1759.

Baradaran R V, Khammar M T, Rakhshandeh H, Samzadeh-Kermani A, Hosseini A \& Askari V R 2019 Crocin protects cardiomyocytes against LPS-Induced inflammation. Pharmacol. Rep. 71: 1228- 1234.

Boukhatem M N \& Setzer W N 2020 Aromatic herbs, medicinal plant-derived essential oils, and phytochemical extracts as potential therapies for coronaviruses: Future perspectives.
Plants 9(6): 800. https://doi.org/10.3390/ plants9060800.

Bousquet J, Cristol J P \& Czarlewski W et al. 2020a Nrf2-interacting nutrients and COVID-19: time for research to develop adaptation strategies. Clin. Transl. Allergy 10: 58. https:// doi.org/10.1186/s13601-020-00362-7.

Bousquet J, Czarlewski W, Zuberbier T \& Mullol J et al. 2020b Spices to control COVID-19 symptoms: Yes, but not only... Int. Arch. Allergy Immunol. doi: 10.1159/000513538.

Bousquet J, Czarlewski W, Zuberbier T, Mullol J, Blain H \& Cristol J et al. 2020c Potential control of COVID-19 symptoms by Nrf2-inter- acting nutrients with TRPA1 (transient receptor potential ankyrin 1) agonist activity. Clin. Transl. Allergy 2020. http://wwwga2lennet.

Bousquet J, Le-Moing V, Blain H, Czarlewski W, Zuberbier $\mathrm{T}$ \& de-la-Torre $\mathrm{R}$ et al. 2020d Efficacy of broccoli and glucoraphanin in COVID-19: From hypothesis to proof-ofconcept with three experimental clinical cases. World Allergy Organ J. 2020: http:// wwwga2lennet/ PDF/06Clinical\%20casesbroccolipdf.

Bousquet J, Czarlewski W \& Zuberbier T et al. 2021 Potential interplay between Nrf2, TRPA1, and TRPV1 in nutrients for the control of COVID-19. Int. Arch. Allergy Immunol. 182: 324-338. https://doi.org/10.1159/000514204

Chai Y S, Chen Y Q, Lin S H, Xie K, Wang C J, Yang Y Z \& Xu F 2020 Curcumin regulates the differentiation of naïve $C D 4+T$ cells and activates IL-10 immune modulation against acute lung injury in mice. Biomed. Pharmacother. 125: 109946.

Chang J S, Wang K C, Yeh C F, Shieh D E \& Chiang L C 2013 Fresh ginger (Zingiber officinale) has anti-viral activity against human respiratory syncytial virus in human respiratory tract cell lines. J. Ethnopharmacol. 145(1): 146-151.

Che D N, Cho B O, Shin J Y, Kang H J, Kim J S, Choi J \& Jang S I 2020 Anti-atopic dermatitis effects of hydrolyzed celery extract in mice. J. Food Biochem. 44: e13198.

Chen L, Lu Y, Zhao L, Hu L, Qiu Q, Zhang Z, Li M, Hong G, Wu B, Zhao G \& Lu Z 2018 Curcumin attenuates sepsis-induced acute organ dysfunction by preventing inflammation and enhancing the suppressive function of Tregs. Int. Immunopharmacol. 61: 1-7. 
Chong L, Zhang W, Nie Y, Yu G, Liu L, Lin L, Wen S, Zhu L \& Li C 2014 Protective effect of curcumin on acute airway inflammation of allergic asthma in mice through Notch1GATA3 signaling pathway. Inflammation 37: 1476-1485.

Choudhary P, Chakdar H, Singh D, Selvaraj C, Singh S K, Kumar S \& Saxena A K 2020 Computational studies reveal piperine, the predominant oleoresin of black pepper (Piper nigrum) as a potential inhibitor of SARSCoV-2 (COVID-19). Curr. Sci. 119(8): 13331342.

Cucinotta D \& Vanelli M 2020 WHO declares COVID-19 a pandemic. Acta Biomed. 91: 157160.

Dai J, Gu L, Su Y, Wang Q, Zhao Y, Chen X, Deng H, Li W, Wang G \& Li K 2018 Inhibition of curcumin on influenza A virus infection and influenzal pneumonia via oxidative stress, TLR2/4, p38/JNK MAPK and NF- $\kappa B$ pathways. Int. Immunopharmacol. 54: 177187.

Dâmaris S, Prieto-Garcia J M, Boylan F, Estrada O, Fonseca-Bazzo Y M \& Jamal C M et al. 2020 COVID-19: Is there evidence for the use of herbal medicines as adjuvant symptomatic therapy. Front. Pharmacol. 11: 581840. https:// doi.org/10.3389/fphar.2020.581840.

Dong Y, Yin Y, Vu S, Yang F, Yarov-Yarovoy V \& Tian Y et al. 2019 A distinct structural mechanism underlies TRPV1 activation by piperine. Biochem. Biophys. Res. Commun. 516(2): 365-372.

Dong Z W, Chen J, Ruan Y C, Zhou T, Chen Y, Chen Y, Tsang L L, Chan H C \& Peng Y Z 2015 CFTR-regulated MAPK/NF- $\kappa B$ signaling in pulmonary inflammation in thermal inhalation injury. Sci. Rep. 5: 15946.

Du T, Shi Y, Xiao S, Li N, Zhao Q, Zhang A, Nan Y, Mu Y, Sun Y, Wu C, Zhang H \& Zhou EM 2017 Curcumin is a promising inhibitor of genotype 2 porcine reproductive and respiratory syndrome virus infection. BMC Vet. Res. 13(1): 298.

Elsayed Y \& Khan N A 2020 Immunity-boosting spices and the novel Coronavirus. ACS Chem. Neurosci. 11, 12: 1696-1698.

Fahanik-Babaei J, Baluchnejadmojarad T, Nikbakht F \& Roghani M 2019 Trigonelline protects hippocampus against intracerebral $A \beta(1-40)$ as a model of Alzheimer's disease in the rat: Insights into underlying mechanisms. Metab. Brain Dis. 34: 191-201.

Fan Y, Zhang Y, Tariq A, Jiang X \& Ahamd Z et al. 2020 Food as medicine: a possible preventive measure against coronavirus disease (COVID-19). Phytother. Res. 34(12): 31243136. https://doi.org/10.1002/ptr.6770.

Fehr A R \& Perlman S 2015 Coronaviruses: An overview of their replication and pathogenesis. Methods Mol. Biol. 1282: 1-23.

Fernandes E S, Fernandes M A \& Keeble J E 2012 The functions of TRPA1 and TRPV1: Moving away from sensory nerves. Br. J. Pharmacol. 166(2): 510-521.

Fisher D \& Heymann D 2020 Q \& A: The novel coronavirus outbreak causing COVID-19. BMC Med. 18: 57. https://doi.org/10.1186/ s12916-020-01533-w.

Forrester S J, Kikuchi D S, Hernandes M S, Xu Q \& Griendling K K 2018 Reactive oxygen species in metabolic and inflammatory signaling. Circ. Res. 122(6): 877-902.

Fu Y, Yang P, Zhao Y, Zhang L, Zhang Z, Dong $X$, Wu Z, Xu Y \& Chen Y 2017 transCinnamaldehyde inhibits microglial activation and improves neuronal survival against neuroinflammation in BV2 microglial cells with lipopolysaccharide stimulation. Evid. Based Complement. Alternat. Med. 2017: 4730878.

Funamoto M, Sunagawa Y, Katanasaka Y, Miyazaki Y, Imaizumi A et al. 2016 Highly absorptive curcumin reduces serum atherosclerotic lowdensity lipoprotein levels in patients with mild COPD. Int. J. Chron. Obstruct. Pulmon. Dis. 11: 2029-2034.

Furue M, Fuyuno Y, Mitoma C, Uchi H \& Tsuji G 2018 Therapeutic agents with AHR inhibiting and NRF2 activating activity for managing chloracne. Antioxidants 7(7): 90.

Ghiasian M, Khamisabadi F, Kheiripour N, Karami M, Haddadi R, Ghaleiha A, Taghvaei B, Oliaie S S, Salehi M, Samadi P \& Ranjbar A 2019 Effects of crocin in reducing DNA damage, inflammation, and oxidative stress in multiple sclerosis patients: A double-blind, randomized, and placebo-controlled trial. J. Biochem. Mol. Toxicol. 33: e22410. 
Gilling D H, Kitajima M, Torrey J R \& Bright K R 2014 Mechanisms of antiviral action of plant antimicrobials against murine norovirus. Appl. Environ. Microbiol. 80: 4898-4910.

Gu S M, Lee H P, Ham Y W, Son D J, Kim H Y, Oh K W, Han S B, Yun J \& Hong J T P L 2018 Improves lipopolysaccharide-induced amyloidogenesis by suppressing NF-KappaB pathway. Neuro Molecular Med. 20: 312-327.

Gupta H, Gupta M \& Bhargava S 2020 Potential use of turmeric in COVID-19. Clin. Exp. Dermatol. 45(7): 902-903.

Gupta M 2010 Pharmacological properties and traditional therapeutic uses of important Indian spices: A review. Int. J. Food Properties 13(5):1092-1116. https://doi. org/10.1080/10942910902963271.

Gupta S C, Sundaram C, Reuter S \& Aggarwal B B 2010 Inhibiting NF- $\kappa B$ activation by small molecules as a therapeutic strategy. Biochim. Biophys. Acta. 1799(10-12) : 775-787.

Han J G, Gupta S C, Prasad S \& Aggarwal B B 2014 PL chemosensitizes tumor cells through interaction with cysteine 179 of $\mathrm{I} \kappa \mathrm{B} \alpha$ kinase, leading to suppression of NF- $\kappa B$-regulated gene products. Mol. Cancer Ther. 13: 2422-2435.

Han Y S, Kim M S \& Hwang J K 2012 Macelignan inhibits histamine release and inflammatory mediator production in activated rat basophilic leukemia mast cells. Inflammation 35: 1723-1731.

Han S, Xu J, Guo X \& Huang M 2018 Curcumin ameliorates severe influenza pneumonia via attenuating lung injury and regulating macrophage cytokines production. Clin. Exp. Pharmacol. Physiol. 45: 84-93.

Hassan M Z, Osman H, Ali M A \& Ahsan M J 2016 Therapeutic potential of coumarins as antiviral agents. Eur. J. Med. Chem. 123 : 236255.

Hayden M, West A \& Ghosh S 2006 NF- $\kappa B$ and the immune response. Oncogene 25: 6758-6780.

Hemeida R A \& Mohafez O M 2008 Curcumin attenuates methotraxate-induced hepatic oxidative damage in rats. J. Egypt Natl. Canc. Inst. 20(2): 141-148.

Hoffmann M, Kleine-Weber H, Schroeder S, Krüger $\mathrm{N}$ et al. 2020 SARS-CoV-2 cell entry depends on ACE2 and TMPRSS2 and is blocked by a clinically proven protease inhibitor. Cell 181: 271-280.e8

Hsieh S L, Chen C T, Wang J J, Kuo Y H, Li C C, Hsieh L C \& Wu C C 2015 Sedanolide induces autophagy through the PI3K, p53 and NF- $\kappa \mathrm{B}$ signaling pathways in human liver cancer cells. Int. J. Oncol. 47: 2240-2246.

Ibrahim M A A, Abdelrahman A H M, Hussien T A et al. 2020 In silico drug discovery of major metabolites from spices as SARS-CoV-2 main protease inhibitors. Comp. Biol. Med. 126: 104046.

Iman V, Mohan S, Abdelwahab S I et al. 2016 Anticancer and anti-inflammatory activities of girinimbine isolated from Murraya koenigii. Drug Des. Devel. Ther. 11: 103-121.

Jagtap S, Khare P, Mangal P, Kondepudi K K, Bishnoi M \& Bhutani K K 2017 Effect of mahanimbine, an alkaloid from curry leaves, on high-fat diet-induced adiposity, insulin resistance, and inflammatory alterations. Biofactors 43: 220-223.

Jiang T A 2019 Health benefits of culinary herbs and spices. J. AOAC Int. 102(2) : 395-411. doi: 10.5740/jaoacint.18-0418.

Jin H, Zhu Z G, Yu P J, Wang G F et al. 2012 Myrislignan attenuates lipopolysaccharideinduced inflammation reaction in murine macrophage cells through inhibition of NF$\kappa \mathrm{B}$ signalling pathway activation. Phytother. Res. 26: 1320-1326.

Joshi G, Sindhu J, Thakur S et al. 2021 Recent efforts for drug identification from phytochemicals against SARS-CoV-2: Exploration of the chemical space to identify druggable leads. Food Chem. Toxicol. 152: 112160. doi:10.1016/j.fct.2021.112160.

Joung E J, Li M H, Lee H G et al. 2007 Capsaicin induces heme oxygenase- 1 expression in HepG2 cells via activation of PI3K-Nrf2 signaling: $\mathrm{NAD}(\mathrm{P}) \mathrm{H}$ :quinone oxidoreductase as a potential target. Antioxid. Redox Signal. 9(12): 2087-2098.

Kandeel M \& Al-Nazawi M 2020 Virtual screening and repurposing of FDA approved drugs against COVID-19 main protease. Life Sci. 251: 117627.

Kang P, Kim K Y, Lee H S, Min S S \& Seol G H 2013 Anti-inflammatory effects of anethole 
in lipopolysaccharide-induced acute lung injury in mice. Life Sci. 93: 955-961.

Khanna K, Kohli S K, Kaur R et al. 2021 Herbal immune-boosters: Substantial warriors of pandemic Covid-19 battle. Phytomedicine 85: 153361.

Kim N, Do J, Bae J S, Jin H K, Kim J H, Inn K S, Oh M S \& Lee J K 2018 PL inhibits neuroinflammation via regulating NF- $\kappa \mathrm{B}$ signaling pathways in lipopolysaccharidestimulated BV2 microglia cells. J. Pharmacol. Sci. 137: 195-201.

Koh W S, Yoon S Y, Kwon B M, Jeong T C, Nam K S \& Han M Y 1998 Cinnamaldehyde inhibits lymphocyte proliferation and modulates T-cell differentiation. Int. J. Immunopharmacol. 20: 643-660.

Ku S K, Kim J A \& Bae J S 2014 Piperlonguminine downregulates endothelial protein $C$ receptor shedding in vitro and in vivo. Inflammation 37: 435-442.

Kumar S, Kashyap P, Chowdhury S, Kumar S, Panwar A \& Kumar 2020 Identification of phytochemicals as potential therapeutic agents that binds to Nsp15 protein target of coronavirus (SARS-CoV-2) that are capable of inhibiting virus replication. Phytomedicine 2020: 153317.

Kunnumakkara AB, Rana V, Parama D, Banik K, Girisa S, Sahu H, Thakur KK, Dutta U, Garodia P, Gupta SC \& Aggarwal BB 2021 COVID-19, cytokines, inflammation, and spices: How are they related ? Life Sci. https:// doi.org/10.1016/j.lfs.2021.119201.

Kunnumakkara A B, Sailo B L, Banik K, Harsha C, Prasad S, Gupta S C, Bharti A C \& Aggarwal B B 2018 Chronic diseases, inflammation, and spices: how are they linked. J. Transl. Med. 16: 14 .

Lai P K \& Roy J 2004 Antimicrobial and chemopreventive properties of herbs and spices. Curr. Med. Chem. 11: 1451-1460.

Lai Y, Yan Y, Liao S, Li Y, Ye Y, Liu N, Zhao F \& Xu P 2020 3D-quantitative structure-activity relationship and antiviral effects of curcumin derivatives as potent inhibitors of influenza H1N1 neuraminidase. Arch. Pharm. Res. 43(5): 489-502.

Larmonier C B, Uno J K, Lee K M et al. 2008 Limited effects of dietary curcumin on Th-1 driven colitis in IL-10 deficient mice suggest an IL10-dependent mechanism of protection. Am. J. Physiol. Gastrointest. Liver Physiol. 295(5): G1079-1091.

Lee E H, Shin J H, Kim S S, Lee H, Yang S R \& Seo S R 2019 Laurus nobilis leaf extract controls inflammation by suppressing NLRP3 inflammasome activation. J. Cell Physiol. 234: 6854-6864.

Lee J Y \& Park W 2011 Anti-inflammatory effect of myristicin on RAW 264.7 macrophages stimulated with polyinosinic-polycytidylic acid. Molecules 16: 7132-7142.

Lertnimitphun P, Jiang Y, Kim N, Fu W, Zheng C, Tan H, Zhou H, Zhang X, Pei W, Lu Y \& Xu H 2019 Safranal alleviates dextran sulfate sodium-induced colitis and suppresses macrophage-mediated inflammation. Front. Pharmacol. 10: 1281.

Li F, Shanmugam M K, Chen L, Chatterjee S, Basha J, Kumar A P, Kundu T K \& Sethi G 2013 Garcinol, a polyisoprenylated benzophenone modulates multiple proinflammatory, signaling cascades leading to the suppression of growth and survival of head and neck carcinoma. Cancer Prev. Res. (Phila) 6: 843854.

Li G, Gao Q, Yuan S, Wang L, Altmeyer R, Lan K, Yin F \& Zou G 2017 Characterization of three small molecule inhibitors of enterovirus 71 identified from screening of a library of natural products. Antivir. Res. 143: 85-96.

Li L, Li H \& Li M 2015 Curcumin protects against cerebral ischemia-reperfusion injury by activating JAK2/STAT3 signaling pathway in rats. Int. J. Clin. Exp. Med. 8: 14985-14991.

Li Y, Wang J, Liu Y, Luo X, Lei W \& Xie L 2020 Antiviral and virucidal effects of curcumin on transmissible gastroenteritis virus in vitro. J. Gen. Virol. 101: 1079-1084.

Li Y L, Du Z Y, Li P H, Yan L et al. 2018 Aromaticturmerone ameliorates imiquimod-induced psoriasis-like inflammation of BALB/c mice. Int. Immunopharmacol. 64: 319-325.

Liang J J, Li H R, Chen Y et al. 2019 Diallyl trisulfide can induce fibroblast-like synovial apoptosis and has a therapeutic effect on collageninduced arthritis in mice via blocking NF- $\kappa B$ and Wnt pathways. Int. Immunopharmacol. 71: 132-138. 
Liang Y D, Bai W J, Li C G et al. 2016 Piperine suppresses pyroptosis and interleukin-1 $\beta$ release upon ATP triggering and bacterial infection. Front. Pharmacol. 7: 390.

Liang Z, Nie H, Xu Y et al. 2016 Therapeutic effects of rosmarinic acid on airway responses in a murine model of asthma. Int. Immunopharmacol. 41: 90-97.

Liu Z \& Ying Y 2020 The inhibitory effect of curcumin on virus-induced cytokine storm and its potential use in the associated severe pneumonia. Front. Cell Dev. Biol. 8: 479.

Long J, Qian K, Tan S, Liu J \& Li J 2020 Macelignan protects against renal ischemia-reperfusion injury via inhibition of inflammation and apoptosis of renal epithelial cells. Cell. Mol. Biol. (Noisy-le-grand) 66: 55-59.

Lu C, Zhang B, Xu T et al. 2019 PL reduces ovalbumininduced asthma and airway inflammation by regulating nuclear factor- $\kappa \mathrm{B}$ activation. Int. J. Mol. Med. 44: 1855-1865.

Lu R, Zhao X, Li J et al. 2020 Genomic characterisation and epidemiology of 2019 novel coronavirus: Implications for virus origins and receptor binding. Lancet (London, England) 395: 565574 .

Lu X L, Zhao C H, Yao X L \& Zhang H 2017 Quercetin attenuates high fructose feeding-induced atherosclerosis by suppressing inflammation and apoptosis via ROS-regulated PI3K/AKT signaling pathway. Biomed. Pharmacother. 85: 658-671.

Masters PS 2006 The molecular biology of coronaviruses. Adv. Virus Res. 66: 193-292.

Mathan K M \& Tamizhselvi R 2020 Protective effect of diallyl disulfide against cerulein- induced acute pancreatitis and associated lung injury in mice. Int. Immunopharmacol. 80: 106136.

Mathew D \& Hsu W 2018 Antiviral potential of curcumin. J. Funct. Foods. 40: 692-699.

Maurya V K, Kumar S, Prasad A K, Bhatt M L B \& Saxena S 2020 Structure-based drug designing for potential antiviral activity of selected natural products from Ayurveda against SARS-CoV-2 spike glycoprotein and its cellular receptor. Virus Dis. 31: 179-193.

Minami M, Kita M, Nakaya T, Yamamoto T, Kuriyama H \& Imanishi J 2003 The inhibitory effect of essential oils on herpes simplex virus type-1 replication in vitro. Microbiol. Immunol. 47: 681-684.

Mo M, Li S, Dong Z, Li C, Sun Y, Li A \& Zhao Z 2020 S-allylmercaptocysteine ameliorates lipopolysaccharide-induced acute lung injury in mice by inhibiting inflammation and oxidative stress via nuclear factor kappa B and Keap1/Nrf2 pathways. Int. Immunopharmacol. 81: 106273.

Moghadamtousi S Z, Kadir H A, Hassandarvish P, Tajik H, Abubakar S \& Zandi K 2014 A review on antibacterial, antiviral, and antifungal activity of curcumin. Biomed. Res. Int. 2014: 186864.

Mollazadeh H, Cicero A F G, Blesso C N, Pirro M, Majeed M \& Sahebkar A 2019 Immune modulation by curcumin: The role of interleukin-10. Crit. Rev. Food Sci. Nutr. 59(1): 89-101.

Moran M M \& Szallasi A 2018 Targeting nociceptive transient receptor potential channels to treat chronic pain: Current state of the field. Br. J. Pharmacol. 175(12): 2185-2203.

Mounce B C, Cesaro T, Carrau L, Vallet T \& Vignuzzi M 2017 Curcumin inhibits Zika and chikungunya virus infection by inhibiting cell binding. Antiviral Res. 142: 148e157.

Nalli M, Ortar G, Schiano M A, Di M V \& De P L 2017 Effects of curcumin and curcumin analogues on TRP channels. Fitoterapia 122: 126-131.

Naqvi A A T, Fatima K, Mohammad T et al. 2020 Insights into SARS-CoV-2 genome, structure, evolution, pathogenesis and therapies: Structural genomics approach. Biochim. Biophys. Acta Mol. Basis Dis. 1866: 165878.

Natesh J, Mondal P, Penta D, Salam A A A \& Meeran S M 2021 Culinary spice bioactives as potential therapeutics against SARS-CoV-2: Computational investigation. Comp. Biol. Med. 128: 104102.

Nie Y, Yu K, Li B, Hu Y et al. 2019 S-allyl-1-cysteine attenuates bleomycin-induced pulmonary fibrosis and inflammation via AKT/NF- $\mathrm{BB}$ signaling pathway in mice. J. Pharmacol. Sci. 139: 377-384.

Nolkemper S, Reichling J, Stintzing F C, Carle R \& Schnitzler P 2006 Antiviral effect of aqueous extracts from species of the Lamiaceae family against Herpes simplex virus type 1 and type 2 in vitro. Planta Med. 72: 1378-1382. 
Ogawa N, Kurokawa T \& Mori Y 2016 Sensing of redox status by TRP channels. Cell Calcium 60(2): 115-122.

Okumura Y, Narukawa M, Iwasaki Y et al. 2010 Activation of TRPV1 and TRPA1 by black pepper components. Biosci. Biotechnol. Biochem. 74(5): 1068-1072.

Oso B J, Adeoye A O \& Olaoye I F 2020 Pharmacoinformatics and hypothetical studies on allicin, curcumin, and gingerol as potential candidates against COVID-19associated proteases. J. Biomol. Struct. Dyn. 2020: 1-12.

Panahi Y, Ghanei M, Bashiri S, Hajihashemi A \& Sahebkar A 2015 Short-term curcuminoid supplementation for chronic pulmonary complications due to sulfur mustard intoxication: Positive results of a randomized double-blind placebo-controlled trial. Drug Res. (Stuttg) 65: 567-573.

Panahi Y, Khalili N, Sahebi E, Namazi S, Atkin S L, Majeed M \& Sahebkar A 2017 Curcuminoids plus piperine modulate adipokines in Type 2 diabetes mellitus. Curr. Clin. Pharmacol. 12: 253-258.

Panahi Y, Hosseini M S, Khalili N, Naimi E, Majeed M \& Sahebkar A 2015 Antioxidant and antiinflammatory effects of curcuminoid-piperine combination in subjects with metabolic syndrome: A randomized controlled trial and an updated meta-analysis. Clin. Nutr. 34: 1101-1108.

Panyod S, Ho C T \& Sheen L Y 2020 Dietary therapy and herbal medicine for COVID-19 prevention: A review and perspective. J. Tradit. Complement. Med. 10: 420-427. https://doi.org/10.1016/j.jtcme.2020.05.004.

Paris A, Strukelj B, Renko M, Turk V, Puki M, Umek A \& Korant B 1993 Inhibitory effect of carnosolic acid on HIV-1 protease in cell-free assays. J. Nat. Prod. 56: 1426-1430.

Patel B, Sharma S, Nair N et al. 2021 Therapeutic opportunities of edible antiviral plants for COVID-19. Mol. Cell. Biochem. 476: 23452364.

Pei H, Xue L, Tang M et al. 2020 Alkaloids from black pepper (Piper nigrum L.) exhibit antiinflammatory activity in murine macrophages by inhibiting activation of NF- $\kappa$ B pathway. J. Agric. Food Chem. 68: 2406-2417.
Peng X, Yang T, Liu G, Liu H, Peng Y \& He L 2018 Piperine ameliorated lupus nephritis by targeting AMPK-mediated activation of NLRP3 inflammasome. Int. Immunopharmacol. 65: 448-457.

Periasamy S, Lin C H, Nagarajan B, Sankaranarayanan N V, Desai U R \& Liu M Y 2018 Mucoadhesive role of tamarind xyloglucan on inflammation attenuates ulcerative colitis. J. Funct. Foods 47: 1-10.

Peterfalvi A, Miko E, Nagy T, Reger B, Simon D, Miseta A, Czéh B \& Szereday L 2019 Much more than a pleasant scent: A review on essential oils supporting the immune system. Molecules 24(24): 4530. https://doi. org/10.3390/molecules24244530.

Pieroni A, Vandebroek I, Prakofjewa J et al. 2020 Taming the pandemic: The importance of homemade plant-based foods and beverages as community responses to COVID-19. J Ethnobiol. Ethnomed. 16: 75. https://doi. org/10.1186/s13002-020-00426-9.

Pradeep C R \& Kuttan G 2002 Effect of piperine on the inhibition of lung metastasis induced B16F-10 melanoma cells in mice. Clin. Exp. Metastasis 19: 703-708.

Praditya D, Kirchhoff L, Brüning J, Rachmawati H, Steinmann J \& Steinmann E 2019 Antiinfective properties of the golden spice curcumin. Front Microbiol. 10: 912.

Rabi F A, Al Zoubi M S, Kasasbeh G A, Salameh D M \& Al-Nasser A D 2020 SARS-CoV-2 and Coronavirus disease 2019: What we know so far. Pathogens 9: 231.

Rajagopal H M, Manjegowda S B, Serkad C \& Dharmesh S M 2018 A modified pectic polysaccharide from turmeric (Curcuma longa) with antiulcer effects via anti-secretary, mucoprotective and IL-10 mediated antiinflammatory mechanisms. Int. J. Biol. Macromol. 118: 864-880.

Rajendran M, Roy S, Ravichandran K, Mishra B, Gupta D K, Nagarajan S, Selvaraj R C A \& Provaznik I 2020 In silico screening and molecular dynamics of phytochemicals from Indian cuisine against SARS-CoV2MPro. J. Biomol. Struct. Dynamics DOI: 10.1080/07391102.2020.1845980.

Rakhi N K, Tuwani R, Garg N, Mukherjee J \& Bagler G 2018 SpiceRx: an integrated resource 
for the health impacts of culinary spices and herbs. BioRxiv 273599. doi: https://doi. org/10.1101/273599.

Reichling J, Schnitzler P, Suschke U \& Saller R 2009. Essential oils of aromatic plants with antibacterial, antifungal, antiviral, and cytotoxic properties - An overview. Forsch. Komplementmed. 16: 79-90.

Richart S M, Li Y L, Mizushina Y et al. 2018 Synergic effect of curcumin and its structural analogue (Monoacetyl curcumin) on anti-influenza virus infection. J. Food Drug Anal. 26(3): 1015-1023.

Riveiro M E, De Kimpe N, Moglioni A, Vazquez R, Monczor F, Shayo C \& Davio C 2010 Coumarins: Old compounds with novel promising therapeutic perspectives. Curr. Med. Chem. 2010: 1325-1338.

Rocha F A C \& de Assis M R 2020 Curcumin as a potential treatment for COVID-19. Phytother. Res. 34: 2085-2087.

Roy A, Sarkar B, Celik C, Ghosh A et al. 2020 Can concomitant use of zinc and curcumin with other immunity-boosting nutraceuticals be the arsenal against COVID-19. Phytother. Res. 34(10): 2425-2428. https://doi.org/10.1002/ ptr.6766.

Samadian F, Dalili N, Poor-Reza Gholi F et al. 2017 Evaluation of curcumin's effect on inflammation in hemodialysis patients. Clin. Nutr. ESPEN 22: 19-23.

Sant'Ana M, Souza H R, Possebon L et al. 2020 Effect of PL during exposure to cigarette smoke reduces inflammation and lung injury. Pulm. Pharmacol. Ther. 61: 101896.

Schoeman D \& Fielding BC 2019 Coronavirus envelope protein: Current knowledge. Virol. J. 16: 1-22.

Sekhon-Loodu S, Ziaullah Z, Rupasinghe H P, Wang Y, Kulka M \& Shahidi F 2015 Novel quercetin-3-O-glucoside eicosapentaenoic acid ester ameliorates inflammation and hyperlipidemia. Inflammopharmacology 23: 173-185.

Sen D, Debnath P, Debnath B, Bhaumik S \& Debnath S 2020 Identification of potential inhibitors of SARS-CoV-2 main protease and spike receptor from 10 important spices through structurebased virtual screening and molecular dynamic study. J. Biomol. Struct. Dynamics DOI: 10.1080/07391102.2020.1819883

Seo E J, Fischer N \& Efferth T 2018 Phytochemicals as inhibitors of NF- $\kappa B$ for treatment of Alzheimer's disease. Pharmacol. Res. 129: 262-273.

Shahidi F \& Ambigaipalan P 2015 Phenolics and polyphenolics in foods, beverages and spices: Antioxidant activity and health effects - A review. J. Functional Foods 18 (Part B): 820897.

Shakeri F, Eftekhar N, Roshan N M, Rezaee R, Moghimi A \& Boskabady M H 2019 Rosmarinic acid affects immunological and inflammatory mediator levels and restores lung pathological features in asthmatic rats. Allergol. Immunopathol. (Madr) 47: 16-23.

Shang J, Wan Y, Luo C, Ye G, Geng Q, Auerbach A \& Li F 2020 Cell entry mechanisms of SARSCoV-2. Proc. Natl Acad. Sci. USA 117: 1172711734.

Shin K, Chung H C, Kim D U, Hwang J K \& Lee S H 2013 Macelignan attenuated allergic lung inflammation and airway hyperresponsiveness in murine experimental asthma. Life Sci. 92: 1093-1099.

Shin Y H, Namkoong E, Choi S et al. 2013 Capsaicin regulates the NF- $\kappa B$ pathway in salivary gland inflammation. J. Dent. Res. 92: 547-552.

Son D J, Kim S Y, Han S S et al. 2012 PL inhibits atherosclerotic plaque formation and vascular smooth muscle cell proliferation by suppressing PDGF receptor signaling. Biochem. Biophys. Res. Commun. 427: 349354.

Sordillo P P \& Helson L 2015 Curcumin suppression of cytokine release and cytokine storm. A potential therapy for patients with Ebola and other severe viral infections. In Vivo 29(1): $1-4$.

Srinivasan K 2014 Antioxidant potential of spices and their active constituents. Crit. Rev. Food Sci. Nutr. 54(3): 352-372.

Sun J, Xu P, Du X, Zhang Q \& Zhu Y 2015 Piperlongumine attenuates collagen-induced arthritis via expansion of myeloid-derived suppressor cells and inhibition of the activation of fibroblast-like synoviocytes. Mol. Med. Rep. 11: 2689-2694. 
SunP, LuX, Xu C, Sun W \& Pan B 2020Understanding of COVID-19 based on current evidence. J. Med. Virol. 92(6): 548-551. https://doi. org/10.1002/jmv.25722.

Sung Y Y, Kim S H, Kim D S, Lee J E \& Kim H K 2017 Illicium verum extract and transanethole attenuate ovalbumin-induced airway inflammation via enhancement of Foxp3+ regulatory $\mathrm{T}$ cells and inhibition of Th2 cytokines in mice. Mediators Inflamm. 2017: 7506808.

Sungnak W, Huang N, Bécavin C et al. 2020 SARSCoV-2 entry factors are highly expressed in nasal epithelial cells together with innate immune genes. Nat. Med. 26: 681-687.

Tahmasebi S, El-Esawi M A, Mahmoud Z H, Timoshin A, Valizadeh H \& Roshangar L et al. 2020 Immunomodulatory effects of nanocurcumin on Th17 cell responses in mild and severe COVID-19 patients. J. Cel. Physiol. 236: 5325-5338. doi:10.1002/jcp.30233.

Takeshi M \& Tanaka Y 1981 Purification and characterization of antiviral substance from the bud of Syzyium aromatica. Planta Med. 42: 69-74.

Tamaddonfard E, Erfanparast A, Farshid A A et al. 2019 Safranal, a constituent of saffron, exerts gastro-protective effects against indomethacin-induced gastric ulcer. Life Sci. 224: 88-94.

Tang J, Luo K, Li Y, Chen Q, Tang D, Wang D \& Xiao J 2015 Capsaicin attenuates LPS- induced inflammatory cytokine production by upregulation of LXR $\alpha$. Int. Immunopharmacol. 28: 264-269.

Towers GHN 1989 Photosensitisers from plants and their photodynamic action. Progr. Phytochem. 6: 183-189.

Tsai M L, Chiou Y S, Chiou LY, Ho C T \& Pan M H 2014 Garcinol suppresses inflammationassociated colon carcinogenesis in mice. Mol. Nutr. Food Res. 58: 1820-1829.

Tzeng T F, Liou S S, Chang C J \& Liu I M 2015 6-gingerol protects against nutritional steatohepatitis by regulating key genes related to inflammation and lipid metabolism. Nutrients 7: 999-1020.

Uchio R, Muroyama K, Okuda-Hanafusa C, Kawasaki K, Yamamoto Y \& Murosaki S 2019 Hot water extract of Curcuma longa L. improves serum inflammatory markers and general health in subjects with overweight or prehypertension/mild hypertension: A randomized, double-blind, placebocontrolled trial. Nutrients 11: 1822.

Umesh, Kundu D, Selvaraj C, Singh S K \& Dubey V K 2020 Identification of new anti-nCoV drug chemical compounds from Indian spices exploiting SARS-CoV-2 main protease as target. J. Biomol. Structure Dynamics. doi: 10.1080/07391102.2020.1763202.

Utomo R Y, Ikawati M \& Meiyanto E 2020 Revealing the potency of citrus and galangal constituents to Halt SARS-CoV-2 infection. Preprints 2020030214. https://doi. org/10.20944/preprints202003.0214.v1

Valizadeh H, Abdolmohammadi-vahid S, Danshina S et al. 2020 Nano-curcumin therapy, a promising method in modulating inflammatory cytokines in COVID-19 patients. Int. Immunopharmacol. 89: 107088. doi:10.1016/j.intimp.2020.107088.

Vitali D, Bagri P, Wessels J M et al. 2020 Curcumin can decrease tissue inflammation and the severity of HSV-2 infection in the female reproductive mucosa. Int. J. Mol. Sci. 21(1): 337.

Viuda-Martos M, Ruiz-Navajas Y, FernándezLópez J \& Pérez-Álvarez J A 2011 Spices as functional foods. Crit. Rev. Food Sci. Nutr. 51(1): 13-28.

Vomund S, Schäfer A, Parnham M J, Brüne B \& von Knethen A 2017 Nrf2, the master regulator of anti-oxidative responses. Int. J. Mol. Sci. 18(12): 2772.

Wang C Y, Huang S C, Zhang Y et al. 2012 Antiviral ability of Kalanchoe gracilis leaf extract against Enterovirus 71 and coxsackievirus A16. Evidence-Based Complement. Altern. Med. 2012: 503165.

Wang F, Hou H, Luo Y et al. 2020 The laboratory tests and host immunity of COVID-19 patients with different severity of illness. JCI Insight 5: e137799.

Wang J, Zhang X, Omarini A B \& Li B 2020 Virtual screening for functional foods against the main protease of SARS-CoV-2. J. Food Biochem. 2020: e13481.

Wang X M, Zhang J S, Gao Y T \& Dai Y 2008 Scavenging effects of curcumin on active 
oxygens and its anti-oxidation in vitro. Sci. Technol. Food Ind. 7: 94-98.

Watanabe T \& Terada Y 2015 Food compounds activating thermosensitive TRP channels in Asian herbal and medicinal foods. J. Nutr. Sci. Vitaminol. 61(Suppl): S86-S88.

Weber N D, Andersen D O, North J A, Murray B, Lawson L D \& Hughes B 1992 In vitro virucidal effects of Allium sativa (garlic) extract and compounds. Planta Med. 58: 417-423.

Wen C C, Kuo Y H, Jan J T et al. 2007 Specific plant terpenoids and lignoids possess potent antiviral activities against severe acute respiratory syndrome coronavirus. J. Med. Chem. 50(17): 4087-4095.

Wu C, Liu Y, Yang Y, Zhang P et al. 2020 Analysis of therapeutic targets for SARS-CoV-2 and discovery of potential drugs by computational methods. Acta Pharm. Sin. B. 10(5): 766-788.

Xia T, Gao R, Zhou G, Liu J, Li J \& Shen J 2019 Trans-cinnamaldehyde inhibits IL-1 $\beta$ stimulated inflammation in by suppressing NF- $\kappa \mathrm{B}$ and p38-JNK pathways and exerts chondrocyte protective effects in a rat model of osteoarthritis. Biomed. Res. Int. 2019: 4039472.

Xiao X, Yang M, Sun D \& Sun S 2012 Curcumin protects against sepsis-induced acute lung injury in rats. J. Surg. Res. 176: e31-39.

Xu H, Zhong L, Deng J, Peng J, Dan H, Zeng X, Li T \& Chen Q 2020 High expression of ACE2 receptor of 2019-nCoV on the epithelial cells of oral mucosa. Int. J. Oral Sci. 12: 8.

Xu X Y, Meng X, Li S, Gan R Y, Li Y \& Li H B 2018 Bioactivity, health benefits, and related molecular mechanisms of Curcumin: current progress, challenges, and perspectives. Nutrients 10(10): 1553. doi: 10.3390/ nu10101553.

Yao L, Chen H P \& Ma 2014 Piperlongumine alleviates lupus nephritis in MRL-Fas(lpr) mice by regulating the frequency of Th17 and regulatory T cells. Immunol. Lett. 161: 76- 80.
Yang F \& Zheng J 2017 Understand spiciness: Mechanism of TRPV1 channel activation by capsaicin. Protein Cell 8(3): 169-177.

Yang M Q, Ye L L, Liu X L et al. 2016 Gingerol activates noxious cold ion channel TRPA1 in gastrointestinal tract. Chin. J. Nat. Med. 14(6): 434-440.

Yang X X, Li C M, Li Y F, Wang J \& Huang C Z 2017 Synergistic antiviral effect of curcumin functionalized graphene oxide against respiratory syncytial virus infection. Nanoscale 9(41): 16086-16092.

Yashin A, Yashin Y, Xia X \& Nemzer B 2017 Antioxidant activity of spices and their impact on human health: A review. Antioxidants (Basel) 6(3): 70. doi:10.3390/antiox6030070.

Ye Q, Wang B \& Mao J 2020 The pathogenesis and treatment of the 'Cytokine Storm' in COVID-19. J. Infect. 80: 607-613.

Yin Y, Dong Y, Vu S, Yang F et al. 2019 Structural mechanisms underlying activation of TRPV1 channels by pungent compounds in gingers. Br. J. Pharmacol. 176(17): 3364-3377.

Zahedipour F, Hosseini S A, Sathyapalan T et al. 2020 Potential effects of curcumin in the treatment of COVID-19 infection. Phytother. Res. 34(11): 2911-2920. https://doi.org/10.1002/ ptr.6738.

Zhang B, Swamy S, Balijepalli S et al. 2019 Direct pulmonary delivery of solubilized curcumin reduces severity of lethal pneumonia. FASEB J. 33(12): 13294-13309.

Zhang F, Yang F, Zhao H \& An Y 2015 Curcumin alleviates lung injury in diabetic rats by inhibiting nuclear factor- $\kappa \mathrm{B}$ pathway. Clin. Exp. Pharmacol. Physiol. 42: 956-963.

Zhang Y, Liang D, Dong L et al. 2015 Antiinflammatory effects of novel curcumin analogs in experimental acute lung injury. Respir. Res. 16: 43.

Zhou P, Yang X L, Wang X G et al. 2020 A pneumonia outbreak associated with a new coronavirus of probable bat origin. Nature 579: 270-273. 